\title{
Psychometric properties of a Spanish version of the 10-item Berger's stigma scale in Colombia: a validation study
}

\author{
Propiedades psicométricas de una versión en español de la escala de Berger de diez ítems en \\ Colombia: un estudio de validación
}

Jorge L Martínez-Cajas ${ }^{12 *}$, David Montaño², Louise Balfour³ ${ }^{3}$ Héctor Fabio Mueses², Jaime Galindo², Beatriz E Alvarado²,4

\begin{abstract}
Introduction: HIV-related stigma is detrimental to people living with HIV (PLH), and reducing it is essential for achieving an HIV/ AIDS-free generation. Abbreviated stigma scales can improve the feasibility of surveys that broadly explore factors affecting PLH. This study tested the psychometric properties of a Spanish translation of the abbreviated 10-item Berger's HIV stigma scale. Methods: We recruited a sample of 105 PLH regularly attending a specialized clinic in Cali, Colombia. English-to-Spanish and Spanish-to-English back translation was performed of the Berger's 10-item HIV stigma scale. Exploratory and confirmatory factor analyses were carried out to assess its validity. Pre- and post-test reliability (15 days) was estimated with the intra-class correlation coefficient (ICC). Results: The Confirmatory Factor Analysis (CFA) was used to confirm a two-factor solution with three poor items removed, resulting in a 7-item HIV Stigma Scale. The resulting 7-item HIV stigma scale had a Cronbach's alpha of 0.73 with an ICC of 0.83 (CI 95\%: 0.75-0.89). One factor loaded three items related to negative self-image (internalised stigma), and the other four items were related to personalized (enacted) HIV stigma. Both factors were related to depression and adherence to antiretroviral therapy. Conclusion: The Spanish translation of the 10-item HIV stigma scale did not perform well due to problems in items 4, 5, and 6. Rather, a modified 7-item version had a good fit with a two-factor loading in which both HIV stigma factors correlated significantly with depression and HIV medication adherence.
\end{abstract}

Keywords: HIV; stigma; scale; psychometric properties; abbreviated scale; validation.

\section{Resumen}

Introducción: el estigma asociado al VIH atenta contra la salud de las personas que viven con VIH (PVV), así que reducirlo es esencial para erradicar el VIH/SIDA. Las escalas abreviadas para estigma pueden facilitar la ejecución de encuestas amplias sobre factores que afectan a las PVV. Este estudio examinó las propiedades psicométricas de una traducción al español de la escala de Berger de 10 ítems. Métodos: se reclutaron 105 PVV en una clínica de VIH en Cali, Colombia. La escala de Berger de 10 ítems se tradujo del inglés al español y después del español al inglés. La validez de constructo se evaluó con análisis factoriales (exploratorios/confirmatorios). La confiabilidad pre y postest (15 días) se estimó con el coeficiente de correlación intraclase (CCI). Resultados: el análisis factorial confirmó una solución de dos factores carente de tres ítems de pobre desempeño, resultando en una escala final de siete ítems, la cual tuvo un coeficiente alfa de Cronbach de 0,73 y un CCI de 0,83 (IC 95\%: 0,75-0,89). Un factor cargó tres ítems relacionados con autoimagen negativa (estigma internalizado), y otros cuatro ítems relacionados con el estigma personalizado (estigma declarado/ejercido por terceros). Ambos factores estuvieron asociados a depresión y baja adherencia a tratamiento antirretroviral. Conclusión: la escala de 10 ítems en español para estigma asociado al VIH tuvo pobre desempeño por problemas con los ítems 4, 5 y 6 . En cambio, una versión modificada de siete ítems tuvo mejor desempeño, cargando dos factores correlacionados significativamente con depresión y adherencia al tratamiento antirretroviral.

Palabras clave: VIH; estigma; escala; propiedades psicométricas; escala abreviada; validación

Submission date: November $16^{\text {th }} 2019$ - Acceptance date: August $28^{\text {th }} 2020$

(1) Department of Medicine. Queens University, Kingston, Ontario, Canada

(2) Corporación de Lucha contra el SIDA, Cali, Colombia

(3) Ottawa Hospital Research Institute, The Ottawa Hospital at the University of Ottawa, Ontario, Canada

(4) Department of Public Health Sciences, Queens University, Kingston, Ontario, Canada

*Corresponding Author:jm209@queensu.ca 


\section{Introduction}

Colombia has the second-highest prevalence rate of HIV in Latin America, with $0.4 \%$ of the general population, approximately 160000 people affected (UNAIDS, 2018). In men who have sex with men (MSM), it has been reported to be as high as $23.7 \%$ (Rubio Mendoza et al., 2015). HIV testing and linkage to care remain low, both approximating 60\% (Pineirua et al., 2015; Mueses-Marin et al., 2018), and 39\% of HIV-positive individuals in Colombia have a detectable viral load (UNAIDS, 2017a). The United Nations has proposed a Fast-Track strategy aiming at stopping the HIV epidemic by 2030 , which relies on a cascade of care that emphasises HIV diagnosis, linkage to treatment, and retention in care as pillars for future HIV elimination. Many factors of either personal (age, gender/sexual identity), cultural (machismo, religion influence), or contextual nature (stigma, access to health system) (Jaspal \& Williamson, 2017) can compromise the effectiveness of processes throughout the HIV cascade. HIV-related stigma stands out as a highly damaging phenomenon in which people either living with or associated with HIV/AIDS are devalued (UNAIDS, 2003). HIV-related stigma is a global phenomenon that has been found to prevent HIV testing, access to and retention in care, and adherence to treatment, among others (UNAIDS, 2017b). In Colombia, a study on HIV-related stigma in PLH found that respondents had often been excluded from social activities (4-40\% varying by region), family activities (6-60\% varying by region), and had negative feelings associated with living with HIV (37\% felt shame, $46.8 \%$ felt guilty, $38 \%$ had low self-esteem)(ONUSIDA, 2017).

HIV-related stigma in PLH has profound effects on health and well-being and has been consistently associated with lower self-esteem, higher depression and loneliness, poor adherence to antiretroviral treatment (ART), more frequent HIV viremia and poor retention in care (Djellouli \& Quevedo-Gomez, 2015; Zea et al., 2015; Sweeney \& Vanable, 2016; Turan et al., 2017a).

Researchers have developed various scales to measure HIV-related stigma, which differ in complexity and scope. The widely used Berger's stigma scale (Buseh et al., 2008; Franke et al., 2010; Jeyaseelan et al., 2013; Valle et al., 2015) has been validated to measure HIV self-perceived stigma. This scale uses 40 statements in its original version and yields four dimensions from the factor structure:"personalised/enacted stigma, disclosure concerns, negative self-image/ internalised, and concern with public attitudes" thus effectively identifying main stigma mechanisms (Berger et al., 2001). Shorter versions of the Berger's scale have been adapted to facilitate use in special populations and to shorten survey time. An abbreviated 10 -item version of the Berger original 40-item stigma scale, which consists of the items that loaded highest on each subscale on the original factor analysis has been used in various settings to explore associations with different HIV related outcomes (Li et al., 2014; Nostlinger et al., 2015) and offers advantages in terms of the time of completion and acceptability (Wright et al., 2007).

When a validated scale is to be used in a new population that is felt to be substantially different culturally or socially, a validation study in that new population is typically necessary to ensure that it maintains its psychometric properties. The original Berger scale has performed well across several cultures with few limitations, particularly regarding how people from different contexts interpret some of its statements. (Reinius et al., 2018) Therefore, this study sought to validate a Spanish language version of the abbreviated 10-item Berger's scale in a convenience sample of Colombian PLH.

\section{Methods}

\section{Study population}

Recruitment of participants took place at the Corporación de Lucha Contra el SIDA (CLS), which is an outpatient HIV clinic in Cali, Colombia, that offers comprehensive HIV care. In 2013, CLS regularly followed over 500 HIV-positive individuals. Adults ( $\geq 18$ years of age) who received routine care and treatment at CLS were deemed eligible to participate if they were able to provide informed consent. From February 2013 to September 2013, a research assistant approached potential participants during the clinic visits and invited them to join the study, which sought to validate scales for ART adherence, depression, and HIV-related stigma. Thus, 109 individuals were invited to participate, of whom 105 consented. A face-to-face interview was conducted with each participant in a private room at CLS. A single interviewer conducted all interviews, each of which lasted about 30 minutes to 1 hour. Both Queen's University and the CLS Ethics Boards approved the study protocol.

\section{Stigma scale}

The original Berger's scale, published in 2001, consists of 40 statements to which respondents indicate their level of agreement on a 4-point Likert scale (from strongly disagree $=1$ to strongly agree $=4$ ), where higher scores indicate a greater perceived stigma (Berger et al., 2001). An abbreviated 10-item version of the Berger stigma scale was developed by Wright et al. (Wright et al., 2007) and published in 2007. This abbreviated scale attempted to reduce the burden of time and energy for the interview without compromising psychometric properties. The 10 items assess four dimensions of stigma (see table 2): (a) personalised stigma (items 7, 8, and 9), (b) individuals' concerns related to disclosure of his/ her own HIV serostatus (items 1 and 10), (c) negative self-image (items 2, 3, and 4), and (d) individuals' concerns related to public attitudes toward HIV positive people (items 5 and 6). In the current 
study, the abbreviated 10-item English scale was adapted into Spanish through a translation and back-translation process that involved: 1) two separate translations from English into Spanish by two bilingual health professionals highly familiar with HIV care and who are both native speakers of Colombian Spanish; 2) discussion of discrepancies between them; 3) back-translation from Spanish into English by a bilingual psychologist with experience in providing care to $\mathrm{PLH}, 4$ ) debriefing of difficulties in translation, 5) piloting of the Spanish version with a different, smaller sample of PLH receiving care at CLS. The interviewer recorded the pilot interview, and the bilingual research team reviewed the process to ensure that the participants understood the questions. The scale was applied twice to the same participants 15 days apart to allow assessment of reliability. This project was independent of others, one from Peru (Franke et al., 2010), and another study from Spain (Fuster-Ruiz de Apodaca et al., 2015) (see Appendix).

\section{Clinical correlates of HIV stigma: Depression and HIV medication adherence}

We studied two important correlates of HIV stigma, namely adherence to antiretroviral medications and depressive symptoms. The ART General Adherence Scale (AGAS) was used to assess adherence (Holstad et al., 2010). The AGAS is a five-item scale that assesses a person's ability to take antiretroviral therapy as recommended by health providers. Responses are reported on a 6-point Likert scale with responses ranging from 1 (none of the time) to 6 (all the time). The AGAS total scores range from 5-30, with higher scores indicating higher levels of adherence (Cronbach's alpha $=0.70$ ). In this study, we used the score of the five items divided by the total possible score as the measure of adherence. For instance, a raw score of 28 would translate into $93 \%$ adherence (see the scale in the appendix). We also dichotomised to define those with adherence of $90 \%$ and over and otherwise. We assessed the presence of depressive symptoms using the Center for Epidemiologic Studies Depression Scale (CES-D). The CES-D has been used in other studies on HIV participants and has been validated in a sample of Colombian PLH (Mueses-Marin et al., 2019).

\section{Other covariates}

Besides the scales above, the questionnaire also included basic socio-demographic questions, such as age, sex, education, housing satisfaction, living arrangements and questions about health-related behaviours, such as smoking, use of injection and non-injection drugs and alcohol, incarceration experience, and use of condoms. The clinical parameters of the participants were obtained from their medical records, including CD4 cell counts and HIV viral load levels. All these factors were included since they are associated with HIV stigma in other studies (Logie \& Gadalla, 2009; Rueda et al., 2016; Sweeney \& Vanable, 2016).

\section{Analysis}

Descriptive statistics were used to summarise sociodemographic characteristics. The internal consistency reliability was tested using Cronbach's alpha coefficient $(\boldsymbol{a})$. Test-retest reliability was assessed using the intraclass correlation coefficient (ICC). Construct validity was conducted to test the presence of the four stigma dimensions- personalised/enacted stigma, disclosure concerns, negative self-image/internalised, and concern with public attitudes -using exploratory and confirmatory factor analyses (CFA). Model fit in CFA was tested using the comparative fit index (CFI) and the Tucker-Lewis index (TLI), where findings of 0.95 or more were considered to indicate adequate fit. The root mean square error of approximation (RMSEA) and standardized root mean square residual (SRMR) were used to estimate how well the model will reproduce the population covariance, with values less than 0.08 indicating a good fit (RB, 2011)C. Convergent validity was tested, exploring correlations between the stigma scale scores with other described factors in the literature. In this case, stigma distribution and correlations were calculated according to adherence, depression, sex, sexual orientation, socioeconomic status, behaviours, and clinical HIV parameters. We performed all analyses using STATA14.

\section{Results}

\section{Description of the sample}

Table 1 summarises the relevant characteristics of the sample. Overall, $72 \%$ were men with an average age of 40 years. Among men, $39.7 \%$ reported being MSM and 16.4\% bisexual. Participants were from different social backgrounds, as reflected by their different levels of education, occupation, and socioeconomic status defined by the area of residence. The frequency of depressive symptoms was high, with half of the sample scoring above the clinical cutoff score of 16 on the CED-S depression scale. At the time of the interview, 20 participants had not started ART, 15 had received ART less than one year, and the remaining had been taking ART for more than one year. Similarly, adherence of $90 \%$ was met by $53 \%$ of persons on ART for less than a year and $48 \%$ of persons on ART for more than a year. Overall, $43 \%$ had detectable viral loads, $94 \%$ in those not yet on treatment, $41.7 \%$ in those who had received treatment less than a year, and $28.5 \%$ in those who had been on treatment for more than a year. 
Table 1: Characteristics of the participants in the validation study, Cali, Colombia.

\begin{tabular}{|c|c|}
\hline Characteristics & CLS n=105 \\
\hline Age, mean years $\pm S D$ ) & $39.6 \pm 9.8$ \\
\hline Sex: Male & $72.4 \%$ \\
\hline $\begin{array}{l}\text { Educational Level: } \\
\text { High school or less } \\
\text { Mean, SD }\end{array}$ & $\begin{array}{l}73.8 \% \\
9.07 ; 3.9\end{array}$ \\
\hline $\begin{array}{l}\text { Occupational status: } \\
\text { Unemployed } \\
\text { Working, full or part time } \\
\text { Housewife } \\
\text { Other (student, retired, etc.) }\end{array}$ & $\begin{array}{l}36.3 \% \\
50.0 \% \\
10.8 \% \\
2.9 \% \\
\end{array}$ \\
\hline $\begin{array}{l}\text { SES of the place of living } \\
1-2 \text { (low-low) } \\
3 \text { (low-middle) } \\
4-6 \text { (middle-high) }\end{array}$ & $\begin{array}{l}62.1 \% \\
26.21 \% \\
11.6 \%\end{array}$ \\
\hline $\begin{array}{l}\text { Living arrangements } \\
\text { Living alone } \\
\text { Family members } \\
\text { Spouse and/or kids } \\
\text { Others }\end{array}$ & $\begin{array}{l}10.7 \% \\
61.2 \% \\
20.4 \% \\
7.7 \% \\
\end{array}$ \\
\hline Has been arrested/incarcerated & $21.4 \%$ \\
\hline Injection drug use & $0 \%$ \\
\hline Having dependent children & $52.4 \%$ \\
\hline $\begin{array}{l}\text { If sexually active, always uses con- } \\
\text { doms }\end{array}$ & $87 \%$ \\
\hline History of drug use & $11.7 \%$ \\
\hline Current smoker & $22.9 \%$ \\
\hline $\begin{array}{l}\text { Alcohol use previous month - } \\
\text { Never } \\
\text { Once per month } \\
\text { More than } 2 \text { or } 3 \text { times per month }\end{array}$ & $\begin{array}{l}57.2 \% \\
31.1 \% \\
11.6 \% \\
\end{array}$ \\
\hline $\begin{array}{l}\text { Depressive symptomatology, } \\
\text { CESD }>=16 \\
\text { Mean, SD }\end{array}$ & $\begin{array}{l}54.2 \% \\
20.4, \text { SD:14.8 }\end{array}$ \\
\hline $\begin{array}{l}\text { Adherence, }<90 \% * \\
\text { Mean, SD }\end{array}$ & $\begin{array}{l}49.4 \% \\
84.7, \text { SD:15.7 }\end{array}$ \\
\hline CD4, Mean; SD & $406 ; 259$ \\
\hline $\begin{array}{l}\text { Viral load, Mean; SD } \\
\text { Detectable viral load }\end{array}$ & $\begin{array}{l}30169 ; 102328 \text { Range } 0-675.000 \\
43 \%\end{array}$ \\
\hline $\begin{array}{l}\text { Exposure to ARV } \\
\text { Less than } 1 \text { year under treatment } \\
\text { More than } 1 \text { year } \\
\text { Ready to start treatment }\end{array}$ & $\begin{array}{l}14.3 \% \\
66.7 \% \\
19.0 \% \\
\end{array}$ \\
\hline
\end{tabular}

*calculated in those receiving treatment

\section{Exploratory and confirmatory analysis}

Table 2 shows the distribution of each of the items of the scale. The most frequent stigma experience was related to disclosure as reflected in percentages of agreement for items 1 and 10, while internalised stigma-related experiences, items 2, 3, and 4, were less frequent. The internal consistency of the ten items measured via
Cronbach's alpha coefficient $(\boldsymbol{a})$ was 0.71 . The ICC of the 10-item scale was 0.79 (95\% Cl: 0.68-0.86). We found low reliability when we considered the four original factors: (a) personalised stigma, Cronbach's alpha 0.67; (b) individual's concern related to the disclosure of his/her own HIV serostatus, Cronbach's alpha 0.27; (c) negative self-image, Cronbach's alpha 0.74; and (d) individuals' concerns related to public attitudes toward HIV positives, Cronbach's alpha 0.59 .

The results of the exploratory factor analysis are also shown in Table 2. An exploratory factor structure was obtained using alpha extraction with oblique varimax rotation. Two factors were found after excluding item 1:"I am very careful whom I tell....."This item has low loading in the two factors and has a high uniqueness index, 0.90 . Eigen values for the two factors were 2.2 and 1.05. The first factor loaded for six items $(5,6,7,8,9,10)$ related to personal and public experiences of stigma, while the other factor load for the three items $(2,3,4)$ related to a negative self-image. We tested this two-factor structure with the nine items using CFA. This model did not render the best-fit estimates, and three correlations between errors needed to be added to obtain the best-fit: between items 5 and 6 , between items 2 and 5, and between items 2 and 6 . Thus, a more parsimonious and best-fit model was obtained by excluding items 5 and 6 (see figure 1). This latest model, with seven items, was considered our final model for the rest of the analysis. Cronbach's alpha for items 2, 3, and 4 was 0.74; Cronbach's alpha for 7, 8, 9, and 10 was 0.71 , and for the 7 -item scale was 0.73 , which means overall good reliability. ICC for the 7-item scale was 0.83 (CI 95\%: 0.75-0.89); for items 2,3 and 4 was 0.78 (Cl95\%0.66-0.86); and for the other 4 items, was $0.79(\mathrm{Cl} 95 \% 0.68-0.86)$.

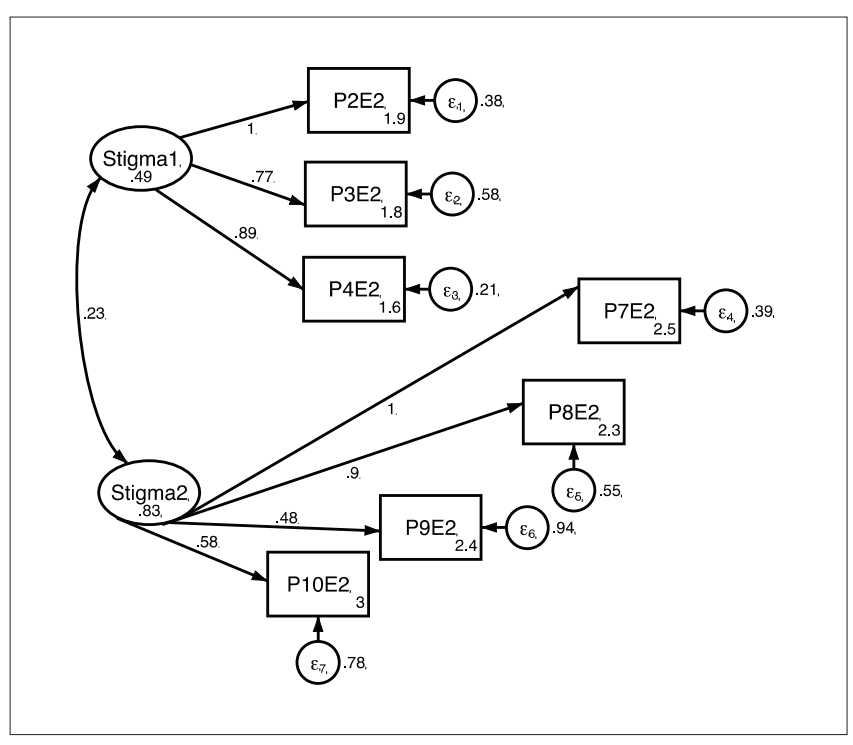

Figure 1: Confirmatory factor analysis of the seven-item Berger scale for $\mathrm{PLH}$ in Cali, Colombia. RMSEA $=0.038 ; \mathrm{CFI}=0.988, \mathrm{TLI}: 0.981 ; \mathrm{SRMR}=0.05$. 
Table 2: Factor structure of the scale obtained with exploratory factor analysis.

\begin{tabular}{|c|c|c|c|c|}
\hline & \multicolumn{2}{|c|}{ Factor Analysis } & \multirow[b]{2}{*}{ Mean, SD } & \multirow[b]{2}{*}{$\begin{array}{l}\text { \% agree or } \\
\text { completely agree }\end{array}$} \\
\hline & $\begin{array}{l}\text { Factor } 1 / \text { personalised (enacted) } \\
\text { and public attitudes }\end{array}$ & $\begin{array}{l}\text { Factor } 2 \text { / negative } \\
\text { self-image (internalised) }\end{array}$ & & \\
\hline Item 1. I am very careful who I tell that I have HIV. & -- & --- & $3.63,0.69$ & 93.5 \\
\hline $\begin{array}{l}\text { Item } 2 \text {. I feel that I am not as good a person as others } \\
\text { because I have HIV. }\end{array}$ & & 0.74 & $1.87,0.93$ & 23.4 \\
\hline Item 3. Having HIV makes me feel unclean. & & 0.55 & $1.82,0.93$ & 21.5 \\
\hline Item 4. Having HIV makes me feel that I'm a bad person. & & 0.71 & $1.61,0.77$ & 11.2 \\
\hline $\begin{array}{l}\text { Item } 5 \text {. Most people think that a person with HIV is } \\
\text { disgusting. }\end{array}$ & 0.32 & & $2.8,1.08$ & 65.4 \\
\hline $\begin{array}{l}\text { Item 6. Most people with HIV are rejected when } \\
\text { others find out. }\end{array}$ & 0.49 & & $3.21,0.82$ & 86.5 \\
\hline $\begin{array}{l}\text { Item } 7 . \text { I have been hurt by how people reacted to } \\
\text { learning I have HIV. }\end{array}$ & 0.73 & & $2.51,1.11$ & 50.5 \\
\hline $\begin{array}{l}\text { Item } 8 . \text { I have stopped socialising with some people } \\
\text { because of their reactions to my having HIV. }\end{array}$ & 0.64 & & $2.26,1.11$ & 40.2 \\
\hline Item 9. I have lost friends by telling them I have HIV. & 0.40 & & $2.37,1.06$ & 43.4 \\
\hline $\begin{array}{l}\text { Item } 10 . \text { I worry that people who know I have HIV } \\
\text { will tell others. }\end{array}$ & 0.46 & & $2.99,1.03$ & 72.6 \\
\hline Cronbach's alpha (a)- & 0.68 & 0.74 & & \\
\hline
\end{tabular}

*Factor loadings from pattern matrix. Loadings $<0.30$ are not shown.

\section{HIV stigma experience and its correlates}

We computed three different scores of the stigma scale. One, adding the value of each of the seven items, with higher scores indicating higher levels of self-perceived stigma. Only one person had 7 points, meaning no stigma experience, and only one person has the maximum score; thus, we observed no ceiling or floor effects. The total HIV stigma score correlates positively with depression, $r$ $=0.45$, thus greater HIV stigma results in a higher number of de- pressive symptoms; and adherence, $r=-0.31$, where higher levels of stigma correlated with low levels of adherence. No significant correlations were found with clinical parameters, age, or education (table 3). Two other scores were constructed: one by adding values with items 2, 3, and 4, and the other with items 7, 8, 9, and 10. The addition of items, 2, 3, and 4, which refer to internalised stigma, was related to depression, adherence, and CD4 levels. The addition of items $7,8,9$, and 10, which refer to personalised/enacted stigma was related to depression and adherence scores. 
Table 3: Spearman correlations of experiences of stigma (total, internalised, enacted) with depression, adherence, CD4 count, HIV viral load, age and education.

\begin{tabular}{l|l|l|l|l|l|l|l}
\hline & Mean, SD & Depression & AGAS & CD4 & Viral load & Age & Years of education \\
\hline $\begin{array}{l}\text { Total stigma- 7 items, } \\
\text { range 7-28 }\end{array}$ & $14.46 ; 4.35$ & $0.45^{*}$ & $-0.31^{*}$ & -0.16 & 0.12 & 0.006 & -0.13 \\
\hline $\begin{array}{l}\text { Factor 2/ negative } \\
\text { self-image (internali- } \\
\text { sed), range: 3-12 }\end{array}$ & $5.32 ; 2.15$ & $0.53^{*}$ & $-0.27^{*}$ & $-0.23^{*}$ & 0.12 & -0.08 & -0.08 \\
\hline $\begin{array}{l}\text { Factor 1/personalised } \\
\text { (enacted) and public } \\
\text { attitudes; range: 4-16 }\end{array}$ & $10.14 ; 3.17$ & $0.26^{*}$ & $-0.24^{*}$ & -0.05 & 0.08 & 0.05 & -0.12 \\
\hline
\end{tabular}

* correlations significant at $p<0.05 ;$ AGAS: ART General Adherence Scale.

Table 4 presents the distribution of means of stigma across other covariates. We found higher levels of stigma in women (in all scores), in men who reported to be heterosexual (total and enacted), in those not satisfied with their housing (total and internalised), and in those previously incarcerated (total and enacted). High levels of stigma (total and enacted) were also related to not consistently using condoms, with detectable viral load (internalised), and low levels of adherence (total and internalised).

Table 4: Distribution of stigma score across categorical variables.

\begin{tabular}{|c|c|c|c|}
\hline & 7-item score & $\begin{array}{l}\text { Factor } 2 / \\
\text { negative } \\
\text { self-image } \\
\text { (internalised) }\end{array}$ & $\begin{array}{l}\text { Factor 1/perso- } \\
\text { nalised (enac- } \\
\text { ted) and public } \\
\text { attitudes }\end{array}$ \\
\hline $\begin{array}{l}\text { Sex } \\
\text { Female } \\
\text { Male }\end{array}$ & $\begin{array}{l}17.4 ; 4.2^{*} \\
14.7 ; 4.2\end{array}$ & $\begin{array}{l}6.17 ; 2.2^{*} \\
5.0 ; 2.0\end{array}$ & $\begin{array}{l}11.2 ; 2.7^{*} \\
9.7 ; 3.2\end{array}$ \\
\hline $\begin{array}{l}\text { SexualOrientation/Men } \\
\text { MSM } \\
\text { Heterosexual } \\
\text { Bisexual }\end{array}$ & $\begin{array}{l}13.4 ; 3.5^{*} \\
16.7 ; 4.21 \\
13.9 ; 4.3\end{array}$ & $\begin{array}{l}5.6 ; 2.14 \\
4.8 ; 2.2 \\
4.8 ; 1.9\end{array}$ & $\begin{array}{l}8.6 ; 2.8^{*} \\
11.1 ; 2.9 \\
9.1 ; 3.2\end{array}$ \\
\hline $\begin{array}{l}\text { Satisfied with housing } \\
\text { Yes } \\
\text { No }\end{array}$ & $\begin{array}{l}14.8 ; 4.5^{*} \\
16.8 ; 3.6\end{array}$ & $\begin{array}{l}4.9 ; 2.0^{*} \\
6.2 ; 2.1\end{array}$ & $\begin{array}{l}9.9 ; 3.3 \\
10.6 ; 2.6\end{array}$ \\
\hline $\begin{array}{l}\text { Ever been incarcerated } \\
\text { No } \\
\text { Yes }\end{array}$ & $\begin{array}{l}15.1 ; 4.4^{*} \\
17.8 ; 2.5\end{array}$ & $\begin{array}{l}5.2 ; 2.2 \\
5.9 ; 1.4\end{array}$ & $\begin{array}{l}9.9 ; 3.2^{*} \\
11.9 ; 1.8\end{array}$ \\
\hline $\begin{array}{l}\text { If sexually active, } \\
\text { always uses condom } \\
\text { No } \\
\text { Yes }\end{array}$ & $\begin{array}{l}18.6 ; 4.2^{*} \\
14.8 ; 4.2\end{array}$ & $\begin{array}{l}5.1 ; 1.9 \\
6.1 ; 3.1\end{array}$ & $\begin{array}{l}12.5 ; 2.6^{*} \\
9.8 ; 3.2\end{array}$ \\
\hline $\begin{array}{l}\text { Viral load } \\
\text { Detectable }(>40) \\
\text { Undetectable }\end{array}$ & $\begin{array}{l}16.27 ; 4.29 \\
14.92 ; 4.18\end{array}$ & $\begin{array}{l}5.95 ; 2.34^{*} \\
5.03 ; 1.92\end{array}$ & $\begin{array}{l}10.32 ; 2.72 \\
9.88 ; 3.41\end{array}$ \\
\hline $\begin{array}{l}\text { Adherence } \\
>90 \% \\
\text { less } \mathbf{9 0 \%}\end{array}$ & $\begin{array}{l}14.23 ; 4.84^{*} \\
16.92 ; 4.84\end{array}$ & $\begin{array}{l}4.53 ; 1.72^{*} \\
5.92 ; 2.44\end{array}$ & $\begin{array}{l}9.69 ; 3.15 \\
11.0 ; 3.34\end{array}$ \\
\hline
\end{tabular}

\section{Discussion}

This study is the first to attempt validation of a Spanish translation of the abbreviated 10-item Berger's stigma scale in PLH in Colombia. Our findings demonstrate that a 7-item abbreviated HIV stigma scale, rather than the 10 -item scale, has good internal reliability and high test-retest reliability ( 15 days) and seems better suited for future use. It is noteworthy that the 7-item scale possesses validity, which is supported by the consistency in the relationship between stigma, depression, and adherence measurements, a feature also reported in other published work (Rueda et al., 2016). The 7-item Spanish version of Berger's scale reported here is also the shorter than those published elsewhere (Franke et al., 2010; Fuster-Ruiz de Apodaca et al., 2015).

In this study, we found that two of the original dimensions of the original scale were represented in the abbreviated 10-item Berger's scale. The way the items are loaded are consistent with two HIV stigma mechanisms: the existence of internalised stigma, such as endorsing negative feelings related to HIV (items, 2, 3, and 4: feelings of being bad, unclean, or not as good as others) and enacted stigma, which involves an individual's experiences with others (being rejected, losing friends, avoiding socialising, worrying about telling others) (Earnshaw et al., 2013). Similar factors were found in a study of Spaniards (Fuster-Ruiz de Apodaca et al., 2015). These two dimensions of HIV-related stigma are of particular importance since internalised stigma (inquired via items $2,3,4)$ seems to enhance the effect of perceived community stigma (inquired with items 7, 8 and 9, also referred to as enacted stigma) on ART treatment adherence, depression, and use of social support (Earnshaw et al., 2013; Logie et al., 2013; Turan et al., 2017a) all of which are central factors determining the health of PLH. Therefore, the 7-item abbreviated scale can adequately measure these two dimensions and can render relevant information for either health care providers or research purposes. This concept is also apparent in our study, where a high correlation of internalised stigma with 
depression, ART adherence, HIV viral load, and CD4 cell levels was found. Also, enacted experiences (items 7 to 10) correlate with depression, were more frequent among women and heterosexual men, and were related to risky behaviours (Balaji et al., 2017), and medication non-adherence (Kerrigan et al., 2017)2017. Enacted and internalised experiences are sources of acute and chronic stress and have been proposed to contribute through these mechanisms to increase risky behaviours, and compromise ART adherence and physical health (Earnshaw et al., 2013; Turan et al., 2017b).

In this study, women reported stronger experiences of stigma than MSM did. This difference could be partially due to recent gains in the rights and recognition of the LGTBQ community in Colombia, which has somewhat mitigated the stigma against them. In contrast, there is an almost nonexistent advocacy movement for HIV-positive women. In general, heterosexual women are a neglected group in HIV campaigns, whose vulnerabilities and marginalisation have not been adequately recognised (Arrivillaga et al., 2012; Prachniak-Rincon \& Villar de Onis, 2016). Traditional gender roles further limit their ability to mobilise against discrimination. Similar findings on higher levels of stigma by sex/gender in studies from Canada, China, and several African countries have been published (Loutfy et al., 2012; Asiedu \& Myers-Bowman, 2014; Li et al., 2016).

We were not able to find a four-factor structure for the 10-item version of the scale in the sample that we recruited. Others have taken a different approach by starting from the original 40-item scale to generate abbreviated versions, with better results. In Peru, the scale was abbreviated to 21 items (Franke et al., 2010), in Spain to 30 (Fuster-Ruiz de Apodaca et al., 2015), in Sweden to 12 (Reinius et al., 2017), and in India to 25 items (Jeyaseelan et al., 2013). Thus, these abbreviated scales had a greater number of items per factor, which were then more likely to fit a 4-factor structure. We decided to start with the 10-item abbreviated scale because data collection was more feasible with a shorter version when applied to the short time available during routine clinical care. Moreover, at the time of initiation of this study, a sufficiently short version in Spanish was not available. Future studies could consider comparing the different abbreviated Spanish versions of the scale, e.g., the one proposed here vs another locally validated short version generated from the original 40-item scale or an abbreviated version.

Disclosure concerns were one of the factors that did not load in our study. Only two items, 1 and 10, of the abbreviated 10-item Berger scale, are related to this concept. The high percentage of respondents agreeing in item 1 related to disclosure, resulting in low variability in the item, could explain the low loading and the high saturation. The disclosure component of the Berger's scale has been found to work differently between Indian and Swedish populations, likely because differences in cultural and social aspects related to disclosure and maintaining the secrecy of diagnosis (Reinius et al., 2018). As disclosure was not well captured in this small sample and this shortened version, future studies could consider validating the 40-item scale or an already 32-item version (Reinius et al., 2018) and including items different from those present in the 10-item version. Further studies may also opt to add a disclosure-concern scale, which was recently validated in Spanish (Hernansaiz-Garrido \& Alonso-Tapia, 2017).

Items 5 and 6 did not load in a unique factor reflecting public attitudes. In the exploratory factor analysis, these items have low item loadings in the two-factor solutions. In the confirmatory factor analysis, their exclusion results in a better fit. Both items refer to perceptions of PLH about the strong attitudes of others toward them. We found difficulties when translating the word disgusting. Other Spanish versions of the Berger scale have used different words to translate the English word disgusting (asquerosa vs despreciable, vs repugnante in our version). It is possible that the word repugnante does not carry the exact meaning of the word disgusting in the cultural context where it was used or that its meaning varied among participants in our sample. Further use of the scale could consider other adjectives or more descriptive phrases.

Our study has limitations. We recruited a convenience sample from among PLH that regularly attended the CLS clinic, which may differ from other PLH receiving care elsewhere in Colombia. Thus, this limits the generalizability of our findings. We do not know if PLH under other care models may have different perceptions about stigma in whom the scale we tested may render different results in terms of reliability and validity. We were unable to fit a better CFA or test the four-factor structure, as this does not converge in our sample. Thus, to encompass all four dimensions of perceived stigma, longer versions may need to be used.

\section{Conclusion}

Although we tested the scale on a relatively small and homogeneous sample, the abbreviated 7-item version of the Berger scale exhibited features that make it appealing for use in the Colombian setting. It is short, easy to conduct and has good internal validity for two perceived stigma dimensions: personalised and internalised stigma. While items 5 and 6 of the 10 -item version had a poor fit, they could be tested in the future, potentially using a more descriptive wording. Given the high levels of stigma experienced and the negative consequences it carries for PLH, a logical next step is to identify interventions at individual and population levels that address internalised and enacted experiences of HIV stigma. We nevertheless believe that the 7-item Spanish abbreviated version 
of the Berger's stigma scale can effectively be used in studies with either a broad-scope inquiry or prospective studies tracking stigma trends over time. Alternatively, it could potentially be used in the clinic as an assessment tool to select patients who may need and benefit from interventions such as building resilient coping skills, mental health promotion and assessment and linkage with support groups.

\section{Author contributions}

BA conceived and designed the study, substantially contributed to the analysis and interpretation of data and the writing of the manuscript. DM contributed to the acquisition, analysis and interpretation of data, and participated in the writing of the first draft. LB conceived and designed the study and critically revised the manuscript. HM contributed to acquisition of data, substantially contributed to data analysis and interpretation. JG contributed to data acquisition of data and critically revised the manuscript. JLM contributed to the study design and data interpretation, critically revised the manuscript, and generated the final version. All authors approved the submitted version and take responsibility for appropriate portions of the content.

\section{Acknowledgements}

We thank the study participants and the CLS personnel for their logistic support in the conduction of this study and Dr Evan Wilson for proofreading and correcting this manuscript. The authors declare no conflict of interest regarding the publication of this paper. The study was funded by Queen's University Principal Grant Funds (PI: Beatriz Alvarado).

\section{References}

Arrivillaga $M$, Springer AE, Lopera M, Correa D, Useche B \& Ross MW. (2012). HIV/AIDS treatment adherence in economically better off women in Colombia. AIDS care 24, 929-935.

Asiedu GB \& Myers-Bowman KS. (2014). Gender differences in the experiences of HIV/AIDS-related stigma: a qualitative study in Ghana. Health care for women international 35, 703-727.

Balaji AB, Bowles KE, Hess KL, Smith JC \& Paz-Bailey G. (2017). Association Between Enacted Stigma and HIV-Related Risk Behaviour Among MSM, National HIV Behavioural Surveillance System, 2011. AIDS and behaviour 21, 227-237.

Berger BE, Ferrans CE \& Lashley FR. (2001). Measuring stigma in people with HIV: psychometric assessment of the HIV stigma scale. Research in nursing \& health 24, 518-529.
Buseh AG, Kelber ST, Stevens PE \& Park CG. (2008). Relationship of symptoms, perceived health, and stigma with quality of life among urban HIV-infected African American men. Public Health Nurs 25, 409-419.

Djellouli N \& Quevedo-Gomez MC. (2015). Challenges to successful implementation of HIV and AIDS-related health policies in Cartagena, Colombia. Soc Sci Med 133, 36-44.

Earnshaw VA, Smith LR, Chaudoir SR, Amico KR \& Copenhaver MM (2013). HIV stigma mechanisms and well-being among PLWH: a test of the HIV stigma framework. AIDS and behaviour 17, 1785-1795.

Franke MF, Munoz M, Finnegan K, Zeladita J, Sebastian JL, Bayona JN \& Shin SS. (2010). Validation and abbreviation of an HIV stigma scale in an adult spanish-speaking population in urban Peru. AIDS and behaviour 14, 189-199.

Fuster-Ruiz de Apodaca MJ, Molero F, Holgado FP \& Ubillos S. (2015). Adaptation of the HIV Stigma Scale in Spaniards with HIV. The Spanish journal of psychology 18, E66.

Hernansaiz-Garrido H \& Alonso-Tapia J. (2017). Internalised HIV Stigma and Disclosure Concerns: Development and Validation of Two Scales in Spanish-Speaking Populations. AIDS and behaviour 21, 93-105.

Holstad MM, Foster V, Diiorio C, McCarty F \& Teplinskiy I. (2010). An examination of the psychometric properties of the Antiretroviral General Adherence Scale (AGAS) in two samples of HIV-infected individuals. The Journal of the Association of Nurses in AIDS Care : JANAC 21, 162-172.

Jaspal R \& Williamson I. (2017). Identity management strategies among HIV-positive Colombian gay men in London. Culture, health \& sexuality $19,1374-1388$.

Jeyaseelan L, Kumar S, Mohanraj R, Rebekah G, Rao D \& Manhart LE. (2013). Assessing HIV/AIDS stigma in south India: validation and abridgement of the Berger HIV Stigma scale. AIDS and behaviour $17,434-443$.

Kerrigan D, Vazzano A, Bertoni N, Malta M \& Bastos Fl. (2017). Stigma, discrimination and HIV outcomes among people living with HIV in Rio de Janeiro, Brazil:The intersection of multiple social inequalities. Global public health 12, 185-199.

Li L, Lin C \& Ji G. (2016). Gendered aspects of perceived and internalised HIV-related stigma in China. Women \& health, 1-13. 
Li MJ, Murray JK, Suwanteerangkul J \&Wiwatanadate P. (2014). Stigma, social support, and treatment adherence among HIV-positive patients in Chiang Mai, Thailand. AIDS education and prevention : official publication of the International Society for AIDS Education 26, 471-483.

Logie C \& Gadalla TM. (2009). Meta-analysis of health and demographic correlates of stigma towards people living with HIV. AIDS care 21, 742-753.

Logie C, James L, Tharao W \& Loutfy M. (2013). Associations between HIV-related stigma, racial discrimination, gender discrimination, and depression among HIV-positive African, Caribbean, and Black women in Ontario, Canada. AIDS patient care and STDs 27, 114-122.

Loutfy MR, Logie CH, Zhang Y, Blitz SL, Margolese SL, Tharao WE, Rourke SB, Rueda S \& Raboud JM. (2012). Gender and ethnicity differences in HIV-related stigma experienced by people living with HIV in Ontario, Canada. PloS one 7, e48168.

Mueses-Marin HF, Martinez Cajas JL, Montano-Agudelo D, Galindo J \& Alvarado-Llano BE. (2019). Propiedades psicométricas y validez de la escala de depresión del Center for Epidemiological Studies (CES-D) en personas atendidas en una clínica de HIV en Cali, Colombia. Biomedica 39.

Mueses-Marin HF, Tello-Bolivar IC, Galindo-Orrego MI \& Galindo-Quintero J. (2018). Perceptions about sexual risk, HIV and HIV-testing in Cali, Colombia. Colomb Med (Cali) 49, 139-147.

Nostlinger C, Bakeera-Kitaka S, Buyze J, Loos J \& Buve A. (2015). Factors influencing social self-disclosure among adolescents living with HIV in Eastern Africa. AIDS care 27 Suppl 1, 36-46.

ONUSIDA. Voce Positivas. Resultados del Indice de estigma en personas que viven con VIH en Colombia.

Pineirua A, Sierra-Madero J, Cahn P, Guevara Palmero RN, Martinez Buitrago E, Young B \& Del Rio C. (2015). The HIV care continuum in Latin America: challenges and opportunities. The Lancet Infectious diseases 15, 833-839.

Prachniak-Rincon C \& Villar de Onis J. (2016). HIV and the Right to Health in Colombia. Health and human rights 18, 157-169.

RB K. (2011). Principles and practice of structural equation modeling. .

Reinius M, Rao D, Manhart LE, Wiklander M, Svedhem V, Pryor J, Mayer R, Gaddist B, Kumar S, Mohanraj R, Jeyaseelan L, Wettergren L \& Eriksson LE. (2018). Differential item functioning for items in Berger's HIV Stigma Scale: an analysis of cohorts from the Indian,
Swedish, and US contexts. Quality of life research : an international journal of quality of life aspects of treatment, care and rehabilitation 27, 1647-1659.

Reinius M, Wettergren L, Wiklander M, Svedhem V, Ekstrom AM \& Eriksson LE. (2017). Development of a 12-item short version of the HIV stigma scale. Health and quality of life outcomes 15, 115.

Rubio Mendoza ML, Jacobson JO, Morales-Miranda S, Sierra Alarcon CA \& Luque Nunez R. (2015). High HIV Burden in Men Who Have Sex with Men across Colombia's Largest Cities: Findings from an Integrated Biological and Behavioural Surveillance Study. PloS one 10, e0131040.

Rueda S, Mitra S, Chen S, Gogolishvili D, Globerman J, Chambers L, Wilson M, Logie CH, Shi Q, Morassaei S \& Rourke SB. (2016). Examining the associations between HIV-related stigma and health outcomes in people living with HIV/AIDS: a series of meta-analyses. BMJ open 6, e011453.

Sweeney SM \& Vanable PA. (2016). The Association of HIV-Related Stigma to HIV Medication Adherence: A Systematic Review and Synthesis of the Literature. AIDS and behaviour 20, 29-50.

Turan B, Budhwani H, Fazeli PL, Browning WR, Raper JL, Mugavero MJ \& Turan JM. (2017a). How Does Stigma Affect People Living with HIV? The Mediating Roles of Internalised and Anticipated HIV Stigma in the Effects of Perceived Community Stigma on Health and Psychosocial Outcomes. AIDS and behaviour 21, 283-291.

Turan B, Hatcher AM, Weiser SD, Johnson MO, Rice WS \& Turan JM. (2017b). Framing Mechanisms Linking HIV-Related Stigma, Adherence to Treatment, and Health Outcomes. American journal of public health $107,863-869$.

UNAIDS. (2003). Stigma and Discrimination, December, 2003 edn. UNAIDS.

UNAIDS. (2017a). COLOMBIA: treatment cascade. Accedido en http://aidsinfo.unaids.org/ el 10 de octubre de 2019.

UNAIDS. UNAIDS warns that HIV-related stigma and discrimination is preventing people from accessing HIV services. (October 16, 2019).

UNAIDS. (2018). Country factsheets. HIV and AIDS estimates.

Valle A, Trevino AC, Zambrano FF, Urriola KE, Sanchez LA \& Elizondo JE. (2015). Perceived HIV-Associated Stigma among HIV-Seropositive Men: Psychometric Study of HIV Stigma Scale. Frontiers in public health 3, 171. 
Martinez-Cajas et al.

Wright K, Naar-King S, Lam P, Templin T \& Frey M. (2007). Stigma scale revised: reliability and validity of a brief measure of stigma for HIV+ youth. The Journal of adolescent health: official publication of the Society for Adolescent Medicine 40, 96-98.
Zea MC, Reisen CA, del Rio-Gonzalez AM, Bianchi FT, Ramirez-Valles J \& Poppen PJ. (2015). HIV Prevalence and Awareness of Positive Serostatus Among Men Who Have Sex With Men and Transgender Women in Bogota, Colombia. American journal of public health 105, 1588-1595. 